\title{
Protecting the Right of Women during Armed Conflict: What reality for the Implementation of International Humanitarian Law, Human Right Law and International Criminal Law
}

Nana Charles Nguindip

Senior Lecturer in Law, University of Dschang Faculty of Laws and Political Sciences P.O Box 66, Dschang

DOI: $10.36347 /$ sjahss.2020.v08i06.002

| Received: 20.05.2020 | Accepted: 02.06.2020 | Published: 07.06.2020

*Corresponding author: Nana Charles Nguindip

\section{Abstract}

Women as a minority group in every given soceity, are understandably strongly affected by armed conflict. This negative experience becomes very precarious for these women in situations where they are highly affected from the abuse and traumas emanating from the outcome of war especially those countries plague by the disaster of armed conflict. As a preliminary remark, it should be acknowledged that while the effects of armed conflict is not always discernible and quantifiable in women, they remain present and multi-dimensional to such an extent that it would be extremely ambitious for any legal or normative framework to pretend to tackle them holistically. The objective of this paper is in examining the role and place of international humanitarian law, human right law and even criminal law in the protection, and treatment of women in a controlled armed conflict. Continuous increase of abuses, rape, exploitation and even violations of women rights during armed conflict creates an impression at both the international and even legal communities of the efficiency and effective protection of women in armed conflict. The main question to be examined here is in analyzing a comparative study of the three legal frameworks, so as to ascertain their compatibilities, and even to a greater extent, complementarities of the three regimes.

Keywords: The Protection- Women -Armed Conflict-Crossing Legal Borders -Application International Humanitarian Law-Human Right Law- International Criminal Law.

Copyright @ 2020: This is an open-access article distributed under the terms of the Creative Commons Attribution license which permits unrestricted use, distribution, and reproduction in any medium for non-commercial use (NonCommercial, or CC-BY-NC) provided the original author and source are credited.

\section{INTRODUCTION}

The continuous impartation of women's right violations in every controlled armed conflict has been in the ascending platform as aspect of this magnitude continues gaining ground on the international level such as those experienced in the Vienna World Conference on the status of Human Rights 1993, the Beijing World Conference on Women 1995, and the Beijing +5 Conference 2000 as well as by the United Nations General Assembly and the United Nations Commission on Human Rights. In October 2000 the United Nations Security Council also called in its resolution 1325 on "Women, Peace and Security" upon all parties to armed conflict "to respect fully international law applicable to the rights and protection of women and girls involved in armed conflict" and invited the Secretary General to carry out a study on the issue $\left[{ }^{1}\right]$. The subject has continued to be discussed inside the UN

${ }^{1}$ S.C. Res. 1325 (2000), U.N. Doc.S/RES/1325 (Oct. $31,2000)$, paras 9 and 16
System as well as outside as the number of women affected during armed conflict increases $\left[{ }^{2}\right]$. The International Committee of the Red Cross (ICRC), conducted a study describing the adverse effects of armed conflict on women different from those experienced by men in by providing basic regulations and guidelines based on the results of the study on how to practically protect women and girls in armed conflict $\left[{ }^{3}\right]$. The Inter-Agency Standing Committee, an inter-agency forum for the coordination, policy

${ }^{2}$ For the discussion within the U.N. Security Council see its documents S/PRST/2001/31 (Oct. 31, 2001); S/2002/1154 (Oct. 16, 2002); S/PRST/2002/32 (Oct. 31, 2002); S/2004/814 (Oct. 13, 2004); S/PRST/2004/40 (Oct. 28, 2004); S/PRST/2005/52 (Oct. 27, 2005); S/PRST/2006/42 (Nov. 8， 2006)， S/PRST/2007/5 (March 7, 2007).

${ }^{3}$ Charlotte Lindsey, Women Facing War, ICRC Study on the Impact of Armed Conflict on Women (2001); ICRC, Addressing the Needs of Women Affected by Armed Conflict: An ICRC Guidance Document (2004). 
development, and decision-making involving the key humanitarian U.N. and non-U.N. partners such as the International Committee of the Red Cross and the International Federation of the Red Cross also on their part provided special guidelines for gender-based violence interventions in humanitarian settings, which are currently being field tested $\left[{ }^{4}\right]$. At last, when thinking about women in war and their protection of its effects, one must realize that women are not only mothers and housewives, but also politicians, doctors, community leaders, researchers etc. and that they experience conflict in many different ways ranging from active participation as combatants to being targeted as a member of the civilian population. Therefore, women in armed conflict must not automatically be categorized as "vulnerable" or "victims," and protection of women in armed conflict includes much more than mere protection from sexual violence $\left[{ }^{5}\right]$.

\section{The Neceasity in establishing a relationship of International Humanitarian Law and Human Right Law in Armed Conflict}

In order in assessing the law protecting women during armed conflict, it is fundamental in identifying the relevant legal dispositions of international humanitarian law and human rights law applicable in which situation and whom they are binding. In principle, human rights law is at all times applicable be it in times of peace as well as armed conflict. It is out in regulating the relationship between a state and individuals, including and specifically targeted on the own nationals of the respective state. Except for the most essential human rights such as the right to life, the prohibition of torture or cruel, inhuman or degrading treatment, slavery, and servitude, most human rights instruments nevertheless allow states to derogate certain rights in times of public emergency $\left[{ }^{6}\right]$. Contrary to this, international humanitarian law is only applicable in times of armed conflict and cannot be derogated or suspended notwithstanding the implications experienced by the State in question. To identify the

${ }^{4}$ Inter-Agency Standing Committee, Guidelines for Gender-based Violence in Humanitarian Settings, Focusing on the Prevention of and Response to Sexual Violence in Emergencies, available at www.humanitarianinfo.org/iasc/content/subsidi/tfgende r/gbv.asp\#feedback (last visited April, 26, 2007).

${ }^{5}$ Charlotte Lindsey, The Impact of Armed Conflict on Women, in Listening to the Silences: Women and War 35 (Helen Durham \& Tracey Gurd eds., 2005) [hereinafter Lindsey 2005]; Report of the SecretaryGeneral on Women, Peace and Security, U.N. Doc. S/2002/1154 (Oct. 16, 2002),

para. 13.

${ }^{6}$ Article 4, International Covenant on Civil and Political Rights, G.A., Res. 2200A/ XXI, (Dec. 16, 1966), 52, U.N. Doc A/6316 (Dec. 19, 1966), 999 U.N.T.S. 171, (entry into force on Mar. 23, 1976) [hereinafter ICCPR] applicable International Humanitarian Law, there is the need of codification by determining in each case whether a conflict is of international, non-international or internal character. The concept of International Humanitarian Law protects individuals, which fall under the definition of "protected persons" of the respective applicable Geneva Convention $\left.{ }^{7}\right]$ and their Additional Protocols $\left[{ }^{8}\right]$. It does not provide protection for nationals of a given State $\left[{ }^{9}\right]$. Another fundamental difference that exists between International Humanitarian Law and Human Right Law can be examined from the traditional point of view that human rights law binds only states. This means that non-state actors such as armed opposition groups, who may under certain conditions be parties to an armed conflict according to International Humanitarian Law and are thus bound by the latter, and do not correspond to the protection offered by Human Right Law.

Further, human rights are rights of individuals who themselves have the right to complain about violations of their human rights. Consequently, Human Right Law often provides additional protection of the individual whose rights have been violated through enforcement mechanisms established by human rights instruments as such. These are judicial or quasi-judicial bodies overseeing the implementation of the respective Human Right instruments to which individuals may directly complain and who can issue binding decisions to the state concerned. International Humanitarian Law on its part is only binding on the parties to an armed conflict and attributes no rights to the individual victims of armed conflict. Consequently, there are no enforcement mechanisms to which individuals can complain in ensuring that states, respectively the parties

\footnotetext{
${ }^{7}$ The Geneva Convention for the Amelioration of the Condition of the Wounded and Sick in Armed Forces in the Field, Aug. 12, 1949, 75 U.N.T.S. 31, 32; Geneva Convention for the Amelioration of the Condition of the Wounded, Sick and Shipwrecked Members of the Armed Forces at Sea, Aug. 12, 1949, 75 U.N.T.S. 85, 86; Geneva Convention Relative to the Treatment to Prisoners of War, Aug. 12, 1949, 75 U.N.T.S. 135, 136 [hereinafter GC III]; Geneva Convention Relative to the Protection of Civilian Persons in Time of War, Aug. 12, 1949, 75 U.N.T.S. 287, 288 [hereinafter GC IV].

${ }^{8}$ Protocol Additional to the Geneva Conventions of August 12, 1949, and Relating to the Protection of Victims of International Armed Conflicts, June 8, 1977, 1125 U.N.T.S. 3 (entered into force Dec. 7, 1978) [hereinafter AP I]; Protocol Additional to the Geneva Conventions of 12 August 1949, and relating to the Protection of Victims of Non-International Armed Conflicts (Protocol II), June 8, 1977, 1125 U.N.T.S. 609 [hereinafter AP II].

${ }^{9}$ This view is increasingly debated nowadays. Andrew Clapham, Human Rights Obligations of Non-State Actors (2006) and Philip Alston (ed.), Non-State Actors and Human Rights (2005).
} 
of an armed conflict, comply with International Humanitarian Law during an armed conflict [10]. It can thus be concluded that International Humanitarian Law and Human Right Law are generally complementary and a parallel application of the two fields of law is possible. In case, however, an applicable International Humanitarian Law provision contradicts an alredy established Human Right Law provision, international humanitarian law is to be considered as lex specialis to human rights law.

\section{Protecting Women's Right as an Interest under International Humanitarian Law}

The nature of International Humanitarian Law depends on its applicable force to all persons who are directly involved in armed conflict. It is of the opinion that protection should be granted to those hors combat or even those considered as prisoners of war. Thus, women in armed conflict should be granted the same protection as men. Such protection is in conformity with the general principles of International Humanitarian Law that it is applicable to all protected persons without discrimination, and all those protected must be treated humanely, all those who are not directly involved in armed conflict should be given minimum protection, and there should be restriction and prohibition on all weapons which may cause bodily harm to individuals especially the women as they are applicable to men $\left[{ }^{11}\right]$. The law continues by providing that, there should be absolute prohibition on discrimination at the level of sex, race, opinion, language, nationality in the sense that no adverse distinction founded on sex is allowed $\left[{ }^{12}\right]$. This is, however, not a prohibition of differentiation of men and women, but allows differentiation as long as it is favorable as the wording "women shall be treated with all consideration due to their sex" shows $\left[{ }^{13}\right]$. Even though the term consideration is not clearly defined, it is understood to include concepts such as the "weaker" physiological constitution of women that are honor, modesty, pregnancy, and child-birth.

\section{Peculiarity of the Protection conferred by International Humanitarian Law}

International Humanitarian Law has provided special protection to women against any form of

\footnotetext{
${ }^{10}$ In complying with International Humanitarian Law, Individuals, who do not comply with IHL or HRL provisions, may be subject to criminal prosecution in case the non-compliance constitutes a war crime or a crime against humanity.

${ }^{11}$ General principles of International Humanitarian Law , Hans-Peter Gasser, International Humanitarian Law: An Introduction (1993)

${ }^{12}$ Article 12 Geneva Convention I and II, Article 16 Geneva Convention III, Article 27 Geneva Convention IV, Article 75Additional Protocol I, and Article 4 Additional Protocol II.
}

${ }^{13}$ Article 12 GC I and II, and Article 14 GC III violation and inhumane treatment during armed conflicts and recognizes that there is a need of providing particular medical and physical attention to this vulnerable group of persons, which are not always, but often, related to their child-bearing role $\left[{ }^{14}\right]$. About forty of the approximately 560 articles found in the four Geneva Conventions of 1949 and the two Additional Protocols of 1977 have provided utmost consideration and concerned for women. The protection offered to women in treaties related to international humanitarian law and thus in international and non-international armed conflict has emphasized that absolute need and protection granted to women and all rights attached to them during armed conflict $\left[{ }^{15}\right]$. It is therefore necessary in portraying as to which principle of the principles stipulated by international humanitarian law has been a peremptory principle of customary international law which are applicable to women during all armed conflict, and whether this principle is applicable at all times regarding the nature of the conflict be it international or non-international armed conflict to women. It is thus a practical concern in determining whether States in their enforcement of international humanitarian law sees to that fundamental principle of customary law are being implemented to latter in matters and issues concerning women during armed conflict.

\section{The Concept of Sexual Violence and Harassment during armed conflict}

It is great responsiveness in emphasizing that excessive aspect of sexual violence are usually experienced in armed conflict, and most of the time, women are considered as overwhelming majority of sexual violence and rape victims during armed conflict. Article 27(2) of the Geneva Convention IV states that "Women shall be especially protected against any attack on their honor, in particular against rape, enforced prostitution, or any form of indecent assault." The concept of rape and sexual violence are also barbarities upon personal dignity, in particular humiliating and degrading treatment and therefore constitute a violation of common Article 3 to the Geneva Conventions. The fact that rape and sexual violence are not only prohibited as such, constitute torture or inhuman treatment, where such acts or ommision constitute a grave breaches of provisions of the Geneva Conventions and mostly reagrded as war crimes in international armed conflict[16].

\footnotetext{
${ }^{14}$ Judith Gardam \& Michelle Jarvis, Women, Armed Conflict and International Law 19-51 (2001)

${ }^{15}$ Helen Durham, International Humanitarian Law and the Protection of Women, in Listening to the Silences: Women and War 95 (Helen Durham \& Tracey Gurd eds., 2005)
}

16 Article 8(2) (b) (xxii) Rome Statute of the International Criminal Court. Rome Statute of the International Criminal Court, adopted on July 17, 1998 
In non-international armed conflict rape and sexual violence are perpetrated as torture or "degrading treatment" violating common Article 3 to the Geneva Conventions, and defaulters o such crimes have to be prosecuted by the competent jurisdiction.

\section{Respecting Specific Protection in situation of Health, and Assistance}

Customary international humanitarian law provides that specific protection, health and assistance needs of women affected by armed conflict must be respected. Similar provisions are also contained in each of the four Geneva Conventions as well as the first Additional Protocol $\left[{ }^{17}\right]$ as in ensuring that women should be given absolute protection and safety when issues of their health arises, and when they experienced traumatic aspects of armed conflict. Obviously, the specific needs of women differ according to the circumstances they are living in especially in aspect of displaced in detention or at home, but always have to be respected. This provision includes protection against sexual violence as well as separation from men for women in detention (see below c.) and is supposed to ensure that women "receive medical, psychological, and social assistance," when necessary. The respect for specific protection, health, and assistance needs of women also includes particular care for pregnant women and mothers of young children, especially nursing or breast feeding mothers. Similarly to the respective provisions in the Geneva.

Conventions and the Additional Protocols, this rule is furthermore interpreted as to include an obligation to avoid the pronouncement of the death penalty on pregnant mothers or mothers having dependent infants for offences related to the armed conflict and to prohibit its execution on such women $\left[{ }^{18}\right]$.

\section{The aspect of women's living in detention}

Women can be deprived of freedom during armed conflict for a huge variety of reasons. They can be detained as civilian internees, as prisoners of war, as security detainees or for reasons which are not related to the conflict. The four Geneva Conventions and the Additional Protocols contain a number of provisions generally relating to detention, especially the conditions of detention. Foremost, a detention place, irrespective of whether it holds civilian detainees or prisoners of

by the U.N. Diplomatic Conference of Plenipotentiaries on the Establishment of an International Criminal Court, entered into force, July 1, 2002, U.N. Doc. A/CONF.183/9 (1998) [hereinafter Rome Statute]. See also Meron, supra note 26, at 424-428.

17 Article 12(4) GC I and II; Article 14(2) GC III; Article 27 GC IV; Article 8(a) AP I,

${ }^{18}$ Articles 38 and 50 GC IV, Article 76(2) AP I, Article 6(4) AP II. war which need to be hold separately[ $\left.{ }^{19}\right]$ must be safe $\left[{ }^{20}\right]$. With regard to specific protection of women in detention rule 119 of the ICRC study on customary humanitarian law states in accordance with Article 75(5) of AP I that: "Women who are deprived of their liberty must be held in quarters separate from those of men, except where families are accommodated as family units, and must be under the immediate supervision of women $\left[{ }^{21}\right]$ ". This has not been the case experienced. We see how in most cases, women are not separated from the men during detention period, and this produces an adverse impact on the fundamental human rights of these women as the experienced aspects such as rape, and even protracted diseases.

\section{The Place of Human Right in the Protection of Women in Armed Conflict}

Among the most important human rights instruments are the Universal Declaration of Human Rights $1948\left[{ }^{22}\right]$, which influenced, although not binding, the emanation of customary international human rights law, and the two 1966 Covenants on Civil and Political Rights and on Social, Economic and Cultural Rights $\left[{ }^{23}\right]$. The first two instruments contain provisions for the basic protection of individuals such as the rights to life, humane treatment, and freedom, the prohibition of slavery and torture as well as judicial guarantees. It goes without saying that if not derogable respectively not derogated, as the rules warranting basic protection of the individual are of particular significance to women in armed conflict, especially because they provide protection from the state of whom they are nationals.

However, it has repetitively been examined and found that even though women enjoy equality before the law, they remain disadvantaged in society compared to men. Worldwide, women still cannot use their human rights to participate in society and politics like men do. As a consequence women earn less money, are less able to decide about their lives and generally have less access to resources education, health care, legal aid, and financial means than men. Further, because of their sex and the associated lower status in

\footnotetext{
${ }^{19}$ Article 84 GC IV,

${ }^{20}$ Articles 19 and 23 GC III; Article 83 GC IV,

${ }^{21}$ Article 97(4), Article 108(2) GC III, Articles 76(4) and 124(3) GC IV.

${ }^{22}$ Universal Declaration of Human Rights, G.A. Res. 217A(III), U.N. Doc. A/810 (1948) [hereinafter UDHR].
}

${ }^{23}$ International Covenant on Civil and Political Rights, G.A. Res. 2200A (XXI), 21 U.N. GAOR Supp. (No. 16) at 52, U.N. Doc. A/6316 (1966), 999 U.N.T.S. 171 [hereinafter ICCPR]; International

Covenant on Economic, Social and Cultural Rights, opened for signature Dec. 16, 1966, 993 U.N.T.S. 3 (entered into force Jan. 3, 1976) [hereinafter ICESCR] 
most societies, women, and girls are particularly affected by the adverse effects of armed conflict. The general vulnerability of women in armed conflict is, thus, the direct result of the discrimination and disadvantage women are subjected to in many areas of life $\left[{ }^{24}\right]$. The realization of this state of affairs contributed to numerous efforts to empower women in the sense of "human rights are women's rights," in the last two decades so as to enable women to profit of their human rights in the same way as men $\operatorname{do}\left[{ }^{25}\right]$.

\section{Human Right and the protection of Women in Armed Conflict}

The specific human rights protection of women in armed conflict raises two different questions. Firstly, one must examine which human rights are of particular importance for women and whether their applicability brings added value to the protection of women in armed conflict. The other question concentrates on the aims of the instruments for the protection of human rights of women in general and whether they are designed to improve the situation and protection of women during armed conflict.

\section{Rationale for protecting Women during Armed Conflict}

Human rights of particular interest for women in armed conflict are those which extend the protection of women provided by International Humanitarian Law, either substantively or by expanding the scope of application. In this regard rights protecting individuals from arbitrary or excessive state action and thus the socalled civil and political rights are particularly important. Among these rights are the prohibitions of torture and inhuman or degrading treatment such as sexual violence and the right to life, freedom and safety of the person. Other principles, like equality before the law, can also become very critical for women in armed conflict situations, when they suddenly become heads of households. As already discussed that civil and political rights principles can be derogated in emergency situations. This has serious consequences in international armed conflict because a state's own nationals do not fall under the protection provided by the four Geneva Conventions and Additional Protocol I.45 It may also have some relevance in non-

\footnotetext{
${ }^{24}$ Fourth World Conference on Women, Action for Equality Development and Peace, Beijing

Declaration and Platform for Action, U.N. Doc. A/Conf.177/20 (Oct. 17, 1995), para. 135.

${ }^{25}$ The slogan "Women's rights are human rights" goes back to a statement of Hilary Rodham Clinton at the United Nations Fourth World Conference on Women, Beijing, China dated Sept. 5, 1995, available at americanrhetoric.com/speeches/hillaryclintonbeijingspe ech.htm (last visited May 10,
}

2007). international armed conflict in which a state's own nationals may become the "enemy."46 Nevertheless, most of the civil and political rights principles, the socalled first dimension rights, are also reflected in IHL as shown above.

\section{The Situation of Economic, Social, and Cultural Rights}

In aspect of social, economic, and cultural human rights like the right to food, the right to health, the right to adequate living conditions including clean water supply, and the right to education can become crucial to women in armed conflict situations. In modern human rights law these rights have the same significance as civil and political rights. However, the wording of the International Covenant on Economic, Social, and Cultural Rights (ICESCR) shows that states are very reserved to guarantee certain minimum standards. Member states for example "recognize the right of everyone to the enjoyment of the highest attainable standard of physical and mental health," but in order to "achieve the full realization of this right" it is sufficient to create conditions "which would assure to all medical service and medical attention in the event of sickness [26]." It must not be forgotten that social, economic, and cultural human rights are difficult to enforce in developing countries even under peaceful conditions. In an armed conflict situation, which is very volatile and unpredictable, it therefore becomes almost impossible to respect or to simply refer to these rights in practice. The same applies even more with regard to collective human rights of the so-called third generation especially those rights related to peace, development, and a healthy environment. It can thus be concluded that even though these human rights are meaningful to women in armed conflict situations and could at least theoretically improve their protection against the effects of the conflict, especially social, economic, and cultural rights and collective human rights are almost impossible to enforce in such situations. Civil and political rights, however, play an important role in complementing the protection of women provided by International Humanitarian Law. Moreover, the full respect of the human rights of women, which are as discussed still not fully implemented everywhere, might make women less vulnerable to the effects of armed conflict.

\section{Women Protection and the Convention on the Elimination of Discrimination against Women}

Considered as the main instrument offering special protection of human rights of women is the 1979 Convention on the Elimination of Discrimination against women (CEDAW) $\left[{ }^{26}\right]$ and even its 1999

${ }^{26}$ Convention on the Elimination of All Forms of Discrimination Against Women, G.A. Res. 34/180, U.N. GAOR, 34th Sess., Supp. No. 46, U.N. Doc. A/34/36 (Sept. 3, 1981) [hereinafter CEDAW]. 
optional protocol $\left[{ }^{27}\right]$. The raison d'etre of establishing the treaty was in realising the protection accorded to women, even though formal equality had been warranted for some time in most western countries, women still did not enjoy equal opportunities, but continued to be widely discriminated against. Having identified this status quo in many, if not most countries of the world, the CEDAW attempts to enable women to have the same access as men to chances in life by prohibiting all kinds of discrimination against women. This includes "any distinction, exclusion or restriction made on the basis of sex which has the effect or purpose of impairing or nullifying the recognition, enjoyment or exercise by women, irrespective of their marital status, on a basis of equality of men and women, of human rights and fundamental freedoms in the political, economic, social, cultural, civil or any other field $\left[{ }^{28}\right]$ ". It is crucial to note that the original CEDAW is exclusively aimed at states, which "condemn discrimination against women in all its forms, agree to pursue by all appropriate means and without delay a policy of eliminating discrimination against women $\left[{ }^{29}\right]$," but does not give immediate or even enforceable rights to individual women. For example, states are obliged to ensure that women in rural areas have adequate living conditions, including sanitation and water supply, but the concerned women suffering from a lack of access to clean water cannot directly file a complaint to get clean water. In addition, CEDAW does not contain specific provisions on violence against women. Nevertheless, the Committee on the Elimination of Discrimination against Women, the monitoring body of CEDAW, adopted in 1992 a general recommendation on "Violence against Women", in which it refers explicitly to the human right of women "not to be subject to torture, or cruel, inhuman or degrading treatment or punishment $\left[{ }^{30}\right]$ ".

\section{Offering effective protection to women under International Human Right Law and International Humanitarian Law}

It is sometimes argued by feminist scholars that International Humanitarian Law reflects the general discrimination against women in society and that its provisions therefore generally exacerbate their unequal status in society $\left[{ }^{31}\right]$. However, International Humanitarian Law being only applicable during conflict

27 Optional Protocol to the Convention on the Elimination of All Forms of Discrimination Against Women, U.N. Doc. A/RES/54/4 (Oct. 15, 1999).

${ }^{28}$ Article 1 CEDAW

${ }^{29}$ Article 2 CEDAW,

${ }^{30}$ U.N. Committee on the Elimination of Discrimination Against Women (CEDAW), Eleventh Session, General Recommendation 19, U.N. Doc. CEDAW/C/1992/L.1/Add.15 /1992 ( Jan. 20-30, 1992), especially para. 7(b) [hereinafter General Recommendation 19]. and aiming to protect women against effects of armed conflict, it is bound to use the status quo in any given country or context as a starting point so as to provide protection for women in armed conflict. Given that International Humanitarian Law only aims at protecting women in as far as they are victims of war, it does not attempt to change pre-existing social structures or societies are they as unfair and unequal as they may. The critique that IHL reflects a "wrong," even an archaic picture of women in International Humanitarian Law, based on the correct analysis that women are not only "victims," therefore shows the very limited aims of International Humanitarian Law has not been taken into account. Even though this can be seen as disadvantaging women in the sense that International Humanitarian Law does not support women to obtain an equal status in society and equal chances in life (e.g. economically, independently, concerning selfdetermination), because their views are ignored, the aim of International Humanitarian Law unlike Human Right Law as discussed is solely to protect women as victims of armed conflict and not to change society. It has also often been argued that progress concerning women's rights in armed conflict during the last decades has almost exclusively been made with regard to women's human rights, not with regard to their protection in International Humanitarian Law. Looking at the number of written resolutions, statements, and papers this is certainly true as it is more visible than any progress concerning women's protection in international humanitarian law. However, it must not be forgotten that the treaty provisions of IHL protecting women are older than most applicable Human Right Law provisions and must be seen as a product of the time they were drafted in. Moreover, written IHL being made for the exceptional circumstances of armed conflict is more static and therefore less flexible than many areas of human rights law, which are under constant revision by the U.N. bodies concerned. For example, it took years to even agree on a third Additional Protocol introducing an additional emblem. Therefore, progress with regard to the specific protection of women in IHL can only exist in developing the interpretation of the respective rules and progress in this regard is to be observed.

\section{The Position of the International Criminal Law}

The serious and systematic violations of international humanitarian and human rights law in the former Yugoslavia and Rwanda also contributed to the development of international criminal law since the early 1990s. The large scale of serious violations of humanitarian law and human rights including systematic sexual violence and rape in the former Yugoslavia was considered by the Security Council as a threat to international peace and security. It consequently created the International Criminal ad hoc Tribunal for the former Yugoslavia (ICTY) under Chapter VII of the U.N. Charter as a measure to restore 
international peace and security [32]. Similarly, the massive and systematic violations of IHL and HRL during the 1994 conflict in Rwanda led to the creation of the International Criminal ad hoc Tribunal for Rwanda (ICTR) on the basis $\left[{ }^{33}\right]$ of Chapter VII of the U.N. Charter and upon the request of the Rwandan government. While the Security Council explicitly referred to sexual violence in its resolution establishing the ICTY, no such reference to sexual violence against women in its resolution establishing the ICTR despite systematic rape of women during the Rwandan conflict. Nevertheless, both statutes articulate crimes in connection with systematic sexual violence, albeit in a limited manner $\left[{ }^{34}\right]$. However, this did not restrain the two ad hoc tribunals from delivering ground-breaking judgments against perpetrators of rape, and sexual violence during the two conflicts concentrating on the leaders of such crimes $\left[{ }^{35}\right]$. In this regard the Kunarac judgment of the ICTY, in which rape was considered as a crime against humanity (for which the accused were found guilty), and the Akayesu case of the ICTR, in which rape was branded genocide (for which the accused was convicted), need to be mentioned $\left[{ }^{36}\right]$.

\section{The International Criminal Court}

Unlike the statutes of the two ad hoc criminal tribunals the Statute of the International Criminal Court (ICC) has a broader and more complete range of sexual and gender based crimes within its mandate which is to prosecute war crimes, crimes against humanity, and genocide worldwide. So far, however, at the time of writing there has been no conviction by the ICC. However, given the scale of sexual violence during the conflicts and the very limited number of judgments by the ad hoc Tribunals, even though they constitute milestones, it is clear that until now the overwhelming majority of perpetrators remain unpunished. Thus, the real significance of international criminal law in general and the above-mentioned judgments in particular is on the one hand, the recognition it gives to the victims and

${ }^{32}$ S.C. Res 808 (1993), U.N. Doc. S/RES/808 (Feb. 22, 1993), preamble para. 11 and S.C. Res. 823 (1993), U.N. Doc. S/RES/823 (May 25, 1993), preamble para. 3.

${ }^{33}$ S.C. Res. 955 (1994), U.N. Doc. S/RES/955 (Nov. 8, 1994).

${ }^{34}$ Article 5 ICTY-Statute - Crime Against Humanity and Article 4 ICTR-Statute, Violation of Article 3 common to the Four Geneva Conventions of 1949.

${ }^{35}$ Kelly D. Askin, The Jurisprudence of International War Crimes Tribunals: Securing Gender Justice for some Survivors, in Listening to the Silences: Women and War (Helen Durham \& Tracey Gurd eds, 2005).

${ }^{36}$ Prosecutor v. Kunarac, Case No. IT-96-23-TQ IT-9623/1-T, Judgement, Trial Chamber, (Feb. 22, 2001); Prosecutor v. Kunarac, Case No. IT-96-23-Q IT-9623/1A, Judgement, Appeals Chamber, ( June 12, 2002); Prosecutor v. Akayesu, Case No. ICTR-96-4-T, Judgement, (Oct. 2, 1998). on the other hand the symbol set by showing that international community considers rape, and sexual violence as unacceptable behavior in armed conflict whose perpetrators need to be punished. Yet, the necessary and indispensable fight against impunity for the perpetrators of such crimes is only one aspect to stop violations of international humanitarian law protecting women and of women's human rights. With regard to sexual violence in armed conflict it is even more crucial to immediately stop such practices by (almost) any means and to take care of the victims of sexual violence and other violations. Despite the progress made with the creation of the ICC by the Rome Statute, international law, however, continues to have very little means to enforce rules of IHL like the prohibition of rape. Even though rape in armed conflict always constitutes a war crime, and assuming the jurisdiction of the ICC as given, the court only has limited resources and cannot judge every single perpetrator, but only the most important ones.

\section{Punishing War Crimes, a Challenge}

Therefore, impunity and the lack of general prevention of such crimes will remain the necessary consequence, if the respective state is unable or unwilling to effectively enforce these rules through the means of its local authority which also includes municipal centers local women can turn to in case of a threat or danger and to prosecute these crimes on the grassroots level. These conditions are unfortunately for many practical reasons most difficult to fulfil in an armed conflict situation. Moreover, the attempt to raise awareness via measures such as the dissemination of the laws of war to all parties of a conflict, and especially to the persons giving orders, is enmeshed with many practical problems. One of the issues relates to the difficulty to reach and train those persons who are likely to commit such crimes.

\section{CONCLUSION}

It has been proved that, even though Human Right Law and International Humanitarian Law both aim to protect the fundamental rights of women as human beings, their specific aims with regard to women are completely different. Whereas International Humanitarian Law "only" attempts to protect women against the effects of armed conflict, Human Right Law aims at enabling women to participate as much as men in public life and to create equal opportunities for them. Consequently, the protection they provide has to differ as much as the objectives of the provisions of the two different bodies of public international law. With regard to the protection of women in armed conflict they are, thus, not identical nor congruent in the sense that even though closely related they do not provide the same protection of women, nor are their enforcement mechanisms identical. Instead, the two bodies of law influence and complement each other, while their primary aims remain different. Nevertheless, considering the reason women are particularly affected 
by armed conflict lies in the fact that they are discriminated and disadvantaged and thus have a lower status in almost any society than men, Human Right Law aiming to improve the status of women in society can significantly contribute in making women less vulnerable to the effects of armed conflict. By empowering women to take an equal role in society and hence by making women less vulnerable to armed conflict Human Right Law is furthermore crucial in post-conflict situations. It has also been shown that International Humanitarian Law and Human Right Law provide adequate legal protection for women in armed conflict, but that although significant progress concerning the enforcement of legal regulations of International Humanitarian Law and Human Right Law protecting women in armed conflict has been made, there still remains much more to be done in enforcing these rights. It is for example unbearable that sexual violence is still commonplace in today's armed conflicts like in Darfur (Sudan), the eastern provinces of the Democratic Republic of Congo, and the Central African Republic. As discussed above, these problems are only to a minor extent legal, but predominantly political and practical and cannot be solved academically from the outside. Unless the existing rules of International Humanitarian Law protecting women in armed conflict is politically and practically enforced in a way that perpetration become the exemption rather than being the rule and have proven insufficient, new international laws protecting women in armed conflict are unnecessary. 